\title{
Multiple Deprivations and Maternal Care in India
}

By Sanjay $K$. Mohanty

Sanjay K. Mohanty is associate professor, Department of Fertility Studies, International Institute for Population Sciences, Mumbai.

\begin{abstract}
CONTEXT: Research on inequalities in the utilization of maternal health care services is often confined to only the economic domain. Individuals and families living in acute poverty may simultaneously experience multiple dimensions of deprivation, which together may obstruct their access to basic health services. It is important to examine the linkages between multiple deprivations and maternal health care.
\end{abstract}

METHODS: Data from the 2005-2006 Indian National Family Health Survey were used to examine ever-married women's receipt of antenatal care, medical assistance during delivery and postnatal care services across three dimensions of deprivation: education, wealth and health. Bivariate analyses, principal component analyses and binomial logistic regression analyses were conducted.

RESULTS: Thirty-two percent of ever-married Indian women reported being deprived in one of the three dimensions, $18 \%$ in two and $7 \%$ in all three; $43 \%$ were deprived in none. Women deprived in all three dimensions were less likely than those not deprived in any to have received antenatal care (predicted probabilities, $0.3 \mathrm{vs.} 0.8$ ) or postnatal care ( 0.2 vs. 0.7$)$; the likelihood that a birth occurred with medical assistance was smaller for women deprived in three dimensions than for those deprived in none (0.2 vs. 0.8). These patterns held true for all of the larger Indian states. Differentials in utilization of maternal care services across deprivation levels were higher in states where service coverage was low and lower in states where service coverage was high.

CONCLUSION: More research is needed to understand how multiple deprivations are associated with health inequality across cultures and how to use this knowledge to improve delivery of basic health services. International Perspectives on Sexual and Reproductive Health, 2012, 38(1):6-14, doi: 10.1363/3800612

Despite concerted efforts by national and local governments, and by nongovernmental and international organizations, the utilization of maternal health services in developing countries is far from universal and varies strongly within and between countries. ${ }^{1}$ Moreover, income disparity in access to maternal care is widening across and within countries, with poor women receiving fewer services than those who are better off. ${ }^{2-5}$ Antenatal visits have multiple benefits-early detection of pregnancy complications, anemia and related health problems, as well as an increased chance of further health care utilization and contraceptive use-and delivery at a health center significantly reduces maternal and infant deaths. ${ }^{6-9}$ For these reasons, universal access to sexual and reproductive health was integrated as one of the key targets of the MDGs in 2006.

India's progress toward universal access to sexual and reproductive health is of global significance, as India accounts for $17 \%$ of the world's population and more than one-fifth of all maternal and child deaths. ${ }^{10,11}$ Empirical evidence suggests that maternal care has improved in India over the last two decades, but progress has been slow overall and uneven within the country. For example, the proportions of women in India who received at least three antenatal visits for their last pregnancy and medical assis- tance at delivery increased between 1992 and 2006, from $44 \%$ to $51 \%$ and from $35 \%$ to $49 \%$, respectively; ${ }^{12}$ however, the rich-poor ratio (i.e., the ratio of the richest to the poorest wealth quintile) for use of antenatal care remained at 3.3 over the period, while the ratio for use of medical assistance at delivery declined from 5.1 to $4.3 .^{13}$ The probability of receiving medical assistance at delivery in India increased between 1992 and 2006 by only two percentage points among poor women and by 19 points among the nonpoor. ${ }^{14}$ And the proportion of births between 2005 and 2006 that were delivered in a heath center varied from $18 \%$ for women with no education to $86 \%$ for those with 12 or more years of schooling. ${ }^{12}$

In the last two decades, research has contributed to the understanding of economic disparities in health and health care utilization. Many studies used data from Demographic and Health Surveys (DHS) and analyzed inequalities in maternal and child health by household wealth, controlling for other social and demographic confounders. ${ }^{13-18}$ In addition, some outlined the contextual determinants of maternal and child care in different Indian states. ${ }^{19-22}$ Although such research has demonstrated that household wealth plays a key role in health inequality, little attention has been paid to understanding the linkages between multiple dimensions of deprivation and health care utilization. 


\section{Multiple Deprivations: Context, Dimensions and Indicators}

Individuals and families living in acute poverty may simultaneously experience deprivations of income, housing and even basic services such as health care and education, which together may be associated with adverse outcomes greater than those associated with any single type of deprivation. For example, among poor women, individuals without an education may be less likely than those with an education to be aware of the benefits and availability of health services, and also less likely to use such services. Although wealth and education are positively correlated, those who are poor in terms of wealth may not necessarily be poor in terms of education, and vice versa.

A multidimensional measure of deprivation can help researchers to identify clusters of deprivation in certain population groups, study their health-seeking behavior and develop interventions to improve health care. The benefit of using a multidimensional measure over a onedimensional measure has been previously explained. ${ }^{23} \mathrm{We}$ postulate that in a modern, market-oriented economy, the possession or lack of specific basic social and physical necessities can be considered the dividing line between different levels of deprivation and can be linked to the healthseeking behavior of the population.

The first systematic effort to measure multidimensional poverty was undertaken by the United Nations Development Programme (UNDP) with the introduction of the Human Poverty Index 1 (HPI-1) and the Human Poverty Index 2 (HPI-2), ${ }^{24}$ which led to further research on the conceptualization and measurement of multidimensional poverty. ${ }^{25-29}$ In 2010, UNDP introduced the Multidimensional Poverty Index (MPI), which measures poverty and inequality in three key dimensions-education, health and wealth-and does so beyond aggregates (i.e., at the state or regional level, instead of by country). The MPI is unique in its use of individual or household unit data, and thus is an improvement relative to the human poverty indexes. On the basis of specific criteria, the MPI was used to estimate that 1.8 billion people in 104 countries are multidimensionally poor, which is substantially higher than the World Bank's estimate of 1.4 billion people living on $\$ 1$ per day. ${ }^{30}$ Yet despite these efforts, the measurement of multidimensional poverty suffers from both theoretical and methodological challenges; theoretical challenges include contextualizing the dimensions and indicators, while methodological issues include fixing the cut-off point for poor and nonpoor, aggregation of multiple dimensions into a single index, weighting of dimensions and choosing the unit of analysis. ${ }^{31-33}$

In India, the official estimates of poverty are derived from consumption expenditure data collected every five years by the National Sample Survey Organization; however, these estimates are often debated because of such issues as the recall period used, the items included in the basket of goods and services, the price index applied and the appropriate minimum daily calorie threshold. On the basis of mixed-recall period estimates, the proportion of the population living below the poverty line declined from $39 \%$ in $1993-1994$ to $22 \%$ in $2004-2005 .^{34}$ The decline in consumption poverty, however, is not associated with a decline in hunger or an improvement in the health of the population. For example, more than two-fifths of Indian children younger than five are undernourished, and half of women are anemic. ${ }^{12}$ Although the Planning Commission of India has acknowledged the multidimensional nature of poverty, its estimates of poverty continue to be derived from consumption expenditure data.

The aim of this article is to understand the links between multiple deprivations and the use of three maternal health services in India. Although there are a number of studies on dimensions, indicators and measurement of deprivation, few include the application of the MPI, specifically with respect to health care utilization. In addition, an understanding of the inequality in health care utilization across multiple deprivations will shed light on the growing inequality and identify the relative importance of the individual dimensions.

\section{METHODS}

Data

The data for this study were drawn from the Indian National Family Health Survey 3 (NFHS-3), conducted in 2005-2006. Details of the survey design, instrument and findings are available in the national and state reports. ${ }^{12}$ Briefly, the NFHS-3 is a population-based representative survey of 109,041 households and 124,385 women aged 15-49. The household questionnaire contained questions about the age, sex and educational attainment of each member, as well as such economic proxies as housing quality, household amenities, consumer durables and land holdings. The women's questionnaire covered demographic information and data on the health and nutrition of mothers and their children born in the five years preceding the survey. Data from the NFHS-3 are comprehensive and are the best available to measure the multiple deprivations of women, as they can be used to link education, wealth, health and related variables to antenatal care, care during delivery and postnatal care of every mother surveyed.

The analytical sample in this study was restricted to the 87,129 women who had ever been married, as childbearing in India-and thus, use of maternal health careoverwhelmingly occurs among married women. ${ }^{12}$

\section{Deprivation Measures}

Three dimensions of deprivation-education, wealth and health-were used for this study, as they were used in the two Human Poverty Indexes and the MPI. For education, a woman was considered deprived if she reported in her individual survey that neither she nor her partner had completed five years of schooling. This cut-off was chosen because couples with little education are often found to have health-seeking behavior similar to those with no 
education. ${ }^{12}$ In addition, the basic education level is increasing in much of India, so the proportion of women with no schooling is low. The cut-off point makes it possible to conduct state-level analyses on maternal care utilization for each category of deprivation by ensuring an adequate sample. Fifty-six percent of ever-married women aged 15-49 and 37\% of their husbands had not completed a single year of schooling; in 32\% of couples, neither the husband nor the wife had completed five or more years of schooling.

The NFHS-3, like most surveys in the DHS series, did not collect data using a direct economic measure such as consumption or income of household. So, to measure wealth in this study, household economic proxieshousing quality, household amenities and consumer durables-were used to construct two composite wealth indexes: one for rural areas and one for urban areas. Separate indexes for rural and urban areas were preferred because health estimates differ significantly by geographical area. ${ }^{35}$ Being economically deprived was defined on the basis of poverty cut-off points from the Planning Commission of India's 2004-2005 official estimates (28\% of the population in rural areas and $26 \%$ of the population in urban areas), which were derived from consumption expenditure data. ${ }^{34}$ This is based on the assumption that households that are poor in terms of income or consumption are also likely to be poor in terms of wealth. Household files were merged with corresponding files for individual women to identify those classified as economically poor.

Body mass index (BMI) was used as the measure of a woman's health and nutrition, as it has been shown in previous research to be positively associated with health, nutrition and the living standard of women. ${ }^{36,37}$ On the basis of internationally used cut-off points, women in the sample were classified as being thin (a BMI of less than $18.5 \mathrm{~kg} / \mathrm{m}^{2}$ ), normal (18.5-25.0) or overweight (greater than 25.0). Thin women were considered to be health deprived, because that category reflects chronic energy deficiency and is associated with adverse pregnancy outcomes, low birth weight, and elevated morbidity and mortality; ${ }^{38}$ pregnant women and women who had given birth within two months of the survey were not included in the computation of BMI.

\section{Dependent Variables}

Three outcomes were studied: antenatal care, medical assistance at delivery and postnatal care. For antenatal care, a measure determined whether a woman had received at least three antenatal care checkups from a health center preceding her last birth in the five years prior to survey; three antenatal visits is the level of care recommended by the reproductive and child health program in India. ${ }^{39}$ Medical assistance at delivery was measured by whether a birth had occurred at home or at a health center, and whether it occurred with assistance from a health professional (a doctor, nurse, auxiliary nurse midwife, lady health visitor or other health personnel); the measure was restricted to women's two most recent live births in the previous five years. Categories included home delivery without medical assistance, home delivery with medical assistance, public health center delivery and private health center delivery. A woman was considered to have received postnatal care if she had a women's health check-up within 42 days of her last birth in the previous five years.

To understand multiple deprivations, a variable integrating the three dimensions of deprivation was constructed. Eight categories of deprivation were possible: education, wealth and health; education and wealth; education and health; wealth and health; education only; wealth only; health only; and none. The first four categories classify deprivation in multiple dimensions, the next three in one dimension and the last category in none.

\section{Analyses}

Descriptive analyses, principal component analysis and binomial logistic regression were used to identify associations between deprivations and utilization of maternal care services. Principal component analysis was used to compute the separate wealth indexes for rural and urban areas. Logistic regression analyses were conducted to identify associations between each of the dependent variables and level of deprivation. Results are shown as predicted probabilities, which are derived from logistic regression; predicted probabilities adjust at the mean of all other independent variables. The national data were sufficient to show differentials in maternal care for all

\begin{tabular}{|c|c|c|c|c|c|}
\hline \multirow[t]{2}{*}{ Characteristic } & \multirow[b]{2}{*}{$\begin{array}{l}\text { All } \\
(\mathrm{N}=87,129)\end{array}$} & \multicolumn{4}{|c|}{ Dimensions of deprivation } \\
\hline & & $\begin{array}{l}\text { None } \\
(\mathrm{N}=37,400)\end{array}$ & $\begin{array}{l}\text { One } \\
(\mathrm{N}=27,555)\end{array}$ & $\begin{array}{l}\text { Two } \\
(\mathrm{N}=15,997)\end{array}$ & $\begin{array}{l}\text { Three } \\
(\mathrm{N}=6,176)\end{array}$ \\
\hline Mean age (yrs.)* & 32.4 & 33.1 & 31.6 & 32.3 & 32.2 \\
\hline$\%$ currently working* & 37.8 & 27.0 & 40.2 & 47.7 & 49.6 \\
\hline Mean yrs. of schooling* & 4.2 & 7.0 & 3.2 & 0.9 & 0.2 \\
\hline Mean no. of children ever born* & 2.9 & 2.5 & 3.0 & 3.5 & 3.8 \\
\hline Mean no. of children surviving & 2.6 & 2.3 & 2.6 & 3.0 & 3.2 \\
\hline$\%$ who had $\geq 1$ birth in last five years* & 37.7 & 33.1 & 39.6 & 41.5 & 47.2 \\
\hline$\%$ living in rural area* & 69.4 & 57.9 & 76.3 & 78.8 & 84.0 \\
\hline$\%$ allowed to go to a health facility alone* & 51.3 & 57.9 & 50.1 & 49.2 & 47.5 \\
\hline$\%$ with a post office/bank account & 16.3 & 25.8 & 11.9 & 6.3 & 3.7 \\
\hline
\end{tabular}




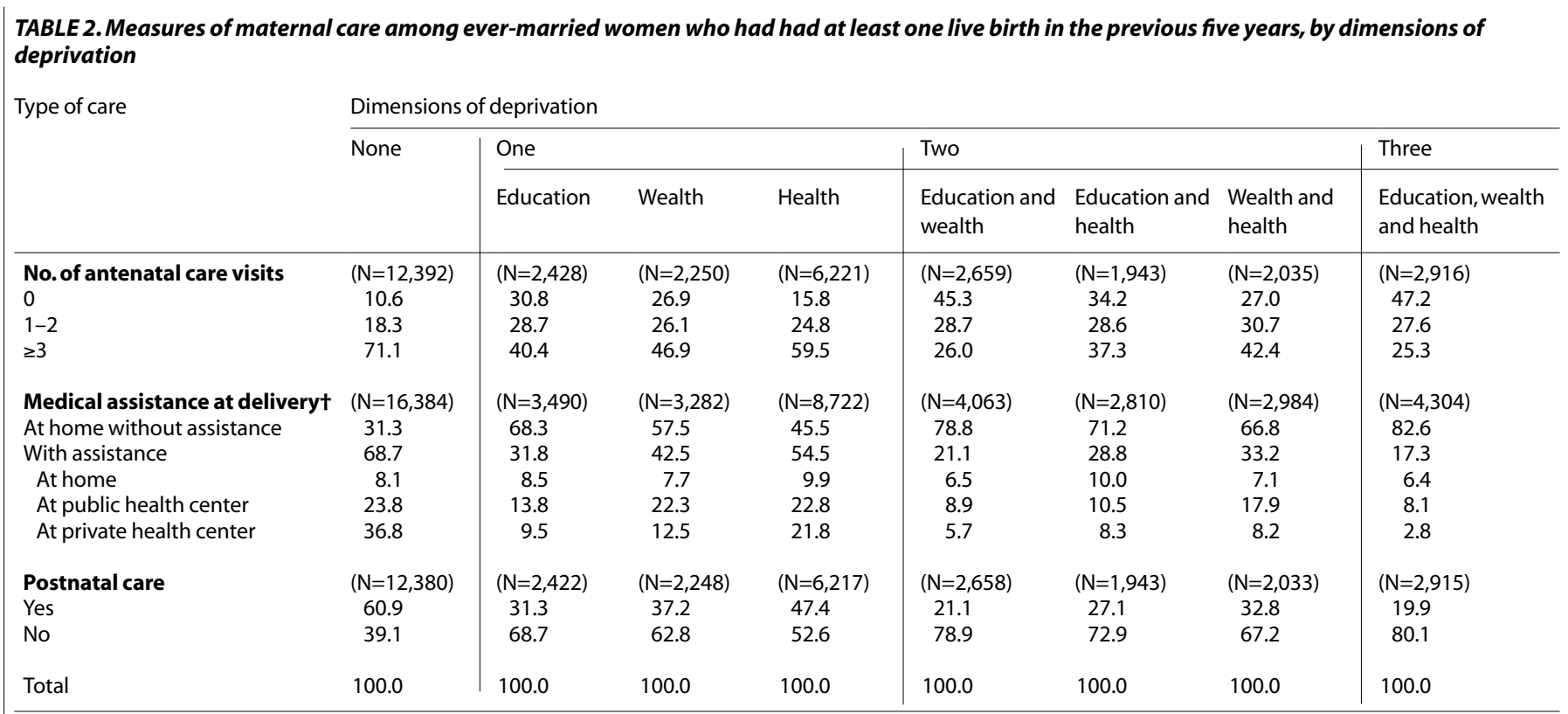

†The unit of analysis for this measure is births; the sample was restricted to women's two most recent live births in the previous five years. Note: All differences are significant across deprivation groups, according to chi-square tests.

eight categories of deprivation; however, the state-level data were adequate for only four groups-deprived in none, deprived in one dimension, deprived in two dimensions and deprived in three dimensions.

\section{RESULTS \\ Descriptive Results}

Overall, 32\% of ever-married women reported being deprived in one dimension, $18 \%$ in two dimensions and $7 \%$ in all three dimensions; $43 \%$ were not deprived in any dimension. The largest group of women with a deprivation were deprived in health only (15\%); followed by education only (11\%); education and health (7\%); education and wealth (7\%); education, health and wealth $(7 \%)$; wealth only $(6 \%)$; and health and wealth $(5 \%)$. The correlation coefficients of dimensional poverty were weak -0.33 for education and wealth, 0.17 for health and wealth, and 0.15 for education and health-indicating that these dimensions are unlikely to overlap.

The mean age of ever-married women was 32 years (Table 1); women with no deprivations were slightly older than those with one, two or three deprivations (mean ages, 33 vs. 32 each). Thirty-eight percent of women reported currently working; greater proportions of women with 1-3 deprivations than of those with none currently worked ( $40-50 \%$ vs. $27 \%$ ). On average, women had had four years of schooling and had borne three children; the level of deprivation was negatively associated with women's mean years of education and positively associated with her mean number of births. Thirty-eight percent of women had had more than one birth in the last five years, $69 \%$ lived in a rural area, $51 \%$ reported being allowed to go to a health facility alone, and $16 \%$ had a post office or bank account; the proportions of women with either of the first two char- acteristics increased with level of deprivation, whereas as the proportions with either of the latter two characteristics decreased with increased deprivation.

Among women who reported at least one live birth in the five years prior to survey, those who were deprived in multiple dimensions were less likely than others to avail themselves of antenatal services (Table 2). Seventy-one percent of women with no deprivation had received at least three antenatal checkups before their last birth, compared with $40-60 \%$ of those deprived in one dimension, $26-42 \%$ of those deprived in two dimensions and $25 \%$ of those deprived in three dimensions. Only $11 \%$ of women with no deprivation had not received even one antenatal checkup, compared with $16-31 \%$ of those deprived in one dimension, $27-45 \%$ of those deprived in two dimensions and $47 \%$ of those deprived in all three dimensions.

The pattern for receipt of medical assistance at delivery was similar to that for antenatal care. Of live births that occurred to ever-married women in the previous five years, the proportion delivered with medical assistance was $69 \%$ among those to women not deprived in any of the three dimensions, compared with $17 \%$ among those to women deprived in all three dimensions. Among women deprived in one dimension, the proportion of births delivered with medical assistance was lowest for those deprived in education $(32 \%)$, followed by those deprived in wealth $(43 \%)$ and those deprived in health (55\%); among women deprived in two dimensions, the proportion of births delivered with medical assistance was lowest among those deprived in education and wealth $(21 \%)$, followed by those deprived in education and health (29\%) and those deprived in wealth and health (33\%).

The pattern for postnatal care is similar to that of the other two outcomes. The proportion of women who had 
FIGURE 1. Among ever-married women who had had at least one live birth in the previous five years, predicted probability of having received antenatal care and postnatal care; and among live births to such women, predicted probability of having been delivered with medical assistance-by dimensions of deprivation

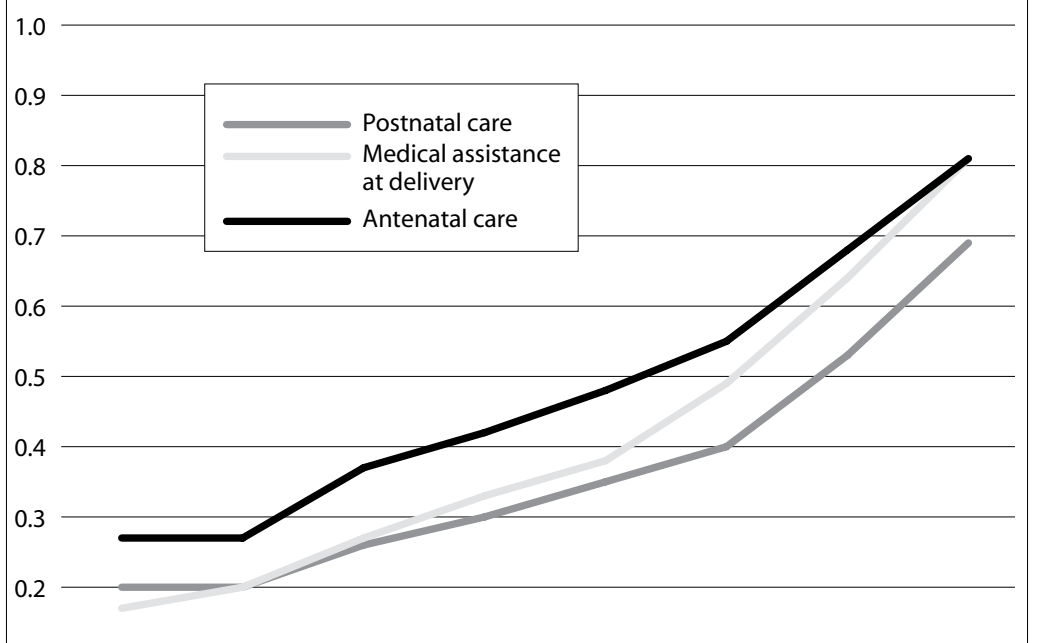

0.1

0.0

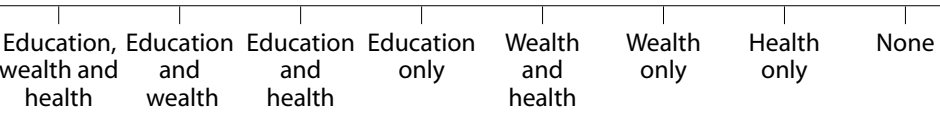

Dimensions of deprivation

Notes: Analyses were adjusted for age of mother, parity, sex of child, caste, religion, region, place of residence and pregnancy complication. For medical assistance at delivery, sample of births was restricted to women's two most recent in the previous five years.

received postnatal care was greater among those with no deprivations than among those with deprivations in all three dimensions (61\% vs. 20\%). Among those deprived in one dimension, the proportion receiving postnatal care was lower for those deprived in education (31\%) than for those deprived in wealth (37\%) or in health (47\%); among

TABLE 3. Percentage of ever-married women who received three or more antenatal care visits for their last live birth in the previous five years, by dimensions of deprivation; and ratio of percentages, by dimensions of deprivation-according to state

\begin{tabular}{|c|c|c|c|c|c|c|c|c|}
\hline \multirow[t]{2}{*}{ India/state } & \multirow[t]{2}{*}{ All } & \multicolumn{4}{|c|}{ Dimensions of deprivation } & \multicolumn{3}{|c|}{ Ratio of none to } \\
\hline & & None & One & Two & Three & One & Two & Three \\
\hline India & 53.5 & 71.1 & 52.6 & 34.3 & 25.3 & 1.4 & 2.1 & 2.8 \\
\hline Andhra Pradesh & 86.0 & 92.5 & 86.7 & 79.3 & 65.9 & 1.1 & 1.2 & 1.4 \\
\hline Assam & 40.2 & 62.8 & 41.5 & 22.1 & 15.0 & 1.5 & 2.8 & 4.2 \\
\hline Bihar & 16.8 & 37.7 & 15.7 & 7.3 & 6.3 & 2.4 & 5.1 & 6.0 \\
\hline Chhattisgarh & 54.5 & 69.6 & 55.8 & 44.6 & 37.9 & 1.2 & 1.6 & 1.8 \\
\hline Gujarat & 68.8 & 81.0 & 66.6 & 47.4 & 30.8 & 1.2 & 1.7 & 2.6 \\
\hline Haryana & 60.7 & 71.4 & 54.8 & 32.9 & 20.0 & 1.3 & 2.2 & 3.6 \\
\hline Jharkhand & 35.5 & 61.8 & 39.7 & 21.5 & 21.5 & 1.6 & 2.9 & 2.9 \\
\hline Karnataka & 79.2 & 87.6 & 80.2 & 62.0 & 52.7 & 1.1 & 1.4 & 1.7 \\
\hline Kerala & 93.7 & 94.4 & 91.0 & $\mathrm{u}$ & $\mathrm{u}$ & 1.0 & $\mathrm{u}$ & $\mathrm{u}$ \\
\hline Madhya Pradesh & 41.6 & 58.7 & 45.8 & 28.2 & 22.6 & 1.3 & 2.1 & 2.6 \\
\hline Maharashtra & 76.1 & 86.7 & 74.2 & 51.7 & 29.7 & 1.2 & 1.7 & 2.9 \\
\hline Orissa & 62.6 & 79.5 & 70.0 & 46.9 & 47.1 & 1.1 & 1.7 & 1.7 \\
\hline Punjab & 76.3 & 84.2 & 64.2 & 50.0 & $\mathrm{u}$ & 1.3 & 1.7 & $\mathrm{u}$ \\
\hline Rajasthan & 41.7 & 59.4 & 41.0 & 26.0 & 15.1 & 1.4 & 2.3 & 3.9 \\
\hline Tamil Nadu & 95.8 & 99.2 & 92.2 & 91.2 & u & 1.1 & 1.1 & $\mathrm{u}$ \\
\hline Uttar Pradesh & 27.3 & 41.5 & 24.4 & 14.8 & 8.9 & 1.7 & 2.8 & 4.6 \\
\hline Uttarakhand & 46.5 & 58.9 & 33.6 & 30.2 & $\mathrm{u}$ & 1.8 & 2.0 & $\mathrm{u}$ \\
\hline West Bengal & 63.0 & 81.7 & 63.5 & 48.5 & 44.7 & 1.3 & 1.7 & 1.8 \\
\hline
\end{tabular}

Notes: $\mathrm{u}=$ unavailable because of small sample size $(\mathrm{N}<30)$. All differences in state comparisons across

deprivation groups are significant, according to chi-square tests. those deprived in two dimensions, the proportion receiving postnatal care varied from $21 \%$ for those deprived in education and wealth, $27 \%$ for those deprived in education and health, and 33\% for those deprived in health and wealth.

Predicted probabilities for each of the three outcomes were estimated, adjusting for such social and demographic variables as age of mother, parity, sex of baby, caste, religion, region, place of residence and pregnancy complications (Figure 1). In general, the predicted probability of postnatal care for each type of deprivation was lower than that of medical assistance at delivery, which in turn was lower than that of antenatal care. Women deprived in all three dimensions were less likely than those not deprived in any to have received antenatal care (predicted probabilities, 0.3 vs. 0.8 ) and postnatal care (0.2 vs. 0.7 ); the likelihood that a birth occurred with medical assistance was lower for women deprived in three dimensions than for those deprived in none (0.2 vs. 0.8). Furthermore, the probability of each outcome was lowest among those deprived in all three dimensions, followed by those deprived in education and wealth, education and health, education only, wealth and health, wealth only, health only and in none. For example, the predicted probability of medical assistance at delivery was 0.17 for births to women deprived in all dimensions, 0.20 for those to women deprived in education and wealth, 0.27 for those to women deprived in education and health, and 0.81 for those to women not deprived in any dimension. The role of education appears to be powerful: After controlling for confounders, women deprived in education alone were less likely to use antenatal services and medical assistance for births than those deprived of both wealth and health.

\section{State-Level Results}

Interstate differences in women's use of maternal care services were explored across 18 of India's larger states, which together are home to more than 95\% of India's population; ${ }^{40}$ the samples in the remaining states were too small for analysis. Service coverage differed considerably across states: Antenatal care ranged from 17\% in Bihar to $96 \%$ in Tamily Nadu (Table 3), and medical assistance at birth ranged from 27\% in Uttar Pradesh to 99\% in Kerala (Table 4). Utilization of maternal care services also differed considerably by dimension of deprivation across states, generally decreasing with increased level of deprivation. For example, in Uttar Pradesh, the proportion of women who had had at least three antenatal care visits and the proportion of births that occurred with medical assistance were greater among women with no deprivations ( $42 \%$ each) than among those deprived in one dimension (24\% and $26 \%$, respectively), two dimensions (15\% and $13 \%$ ) or all three dimensions (9\% each). The exceptions were Kerala, where the overall use of maternal care was high and the differences by dimension of deprivation were small, and Tamil Nadu, where differences were also relatively small 
TABLE 4. Percentage of births to ever-married women in the previous five years that were delivered with medical assistance, by dimensions of deprivation; and ratio of percentages, by dimensions of deprivation-according to state

\begin{tabular}{|c|c|c|c|c|c|c|c|c|}
\hline \multirow[t]{2}{*}{ India/state } & \multirow[t]{2}{*}{ All } & \multicolumn{4}{|c|}{ Dimensions of deprivation } & \multicolumn{3}{|c|}{ Ratio of none to } \\
\hline & & None & One & Two & Three & One & Two & Three \\
\hline India & 47.6 & 68.6 & 46.8 & 27.0 & 17.4 & 1.5 & 2.5 & 3.9 \\
\hline Andhra Pradesh & 75.3 & 86.9 & 73.1 & 63.6 & 61.2 & 1.2 & 1.4 & 1.4 \\
\hline Assam & 31.6 & 54.8 & 31.7 & 16.1 & 9.7 & 1.7 & 3.4 & 5.6 \\
\hline Bihar & 28.7 & 55.8 & 30.1 & 17.5 & 12.2 & 1.9 & 3.2 & 4.6 \\
\hline Chhattisgarh & 40.7 & 59.1 & 44.2 & 26.1 & 22.1 & 1.3 & 2.3 & 2.7 \\
\hline Gujarat & 63.6 & 80.4 & 57.9 & 42.5 & 23.7 & 1.4 & 1.9 & 3.4 \\
\hline Haryana & 50.5 & 64.6 & 43.2 & 16.9 & 23.1 & 1.5 & 3.8 & 2.8 \\
\hline Jharkhand & 28.4 & 58.4 & 30.0 & 17.5 & 10.5 & 1.9 & 3.3 & 5.6 \\
\hline Karnataka & 70.1 & 84.1 & 68.5 & 47.7 & 37.0 & 1.2 & 1.8 & 2.3 \\
\hline Kerala & 99.3 & 99.6 & 98.8 & 94.1 & 100.0 & 1.0 & na & na \\
\hline Madhya Pradesh & 33.1 & 53.6 & 35.9 & 19.2 & 17.2 & 1.5 & 2.8 & 3.1 \\
\hline Maharashtra & 70.1 & 85.2 & 65.5 & 39.5 & 30.1 & 1.3 & 2.2 & 2.8 \\
\hline Orissa & 45.0 & 72.0 & 55.3 & 27.3 & 18.0 & 1.3 & 2.6 & 4.0 \\
\hline Punjab & 69.0 & 78.3 & 54.8 & 47.4 & $\mathrm{u}$ & 1.4 & 1.7 & $\mathrm{u}$ \\
\hline Rajasthan & 41.8 & 59.1 & 44.7 & 24.1 & 13.9 & 1.3 & 2.4 & 4.2 \\
\hline Tamil Nadu & 90.3 & 94.2 & 89.8 & 80.1 & 71.4 & 1.0 & 1.2 & 1.3 \\
\hline Uttar Pradesh & 27.3 & 42.2 & 25.8 & 13.0 & 8.8 & 1.6 & 3.2 & 4.8 \\
\hline Uttarakhand & 39.9 & 54.1 & 27.0 & 17.4 & $\mathrm{u}$ & 2.0 & 3.1 & $\mathrm{u}$ \\
\hline West Bengal & 48.1 & 78.2 & 49.0 & 31.9 & 18.1 & 1.6 & 2.4 & 4.3 \\
\hline
\end{tabular}

Notes: Sample was restricted to women's two most recent births in the previous five years. $\mathrm{u}=$ unavailable because of small sample size $(\mathrm{N}<30)$. All differenc-

es in state comparisons across deprivation groups are significant, according to chi-square tests.

To better understand the inequality in the use of maternal care across deprivation groups, ratios were calculated to compare the service utilization of women not deprived in any dimension with that of women deprived in one, two or three dimensions; the closer the ratio is to 1.0 , the lower the inequality is between the groups. For antenatal care, the ratio of women deprived in no dimension to those deprived in one dimension was highest in Bihar (2.4), Uttarakhand (1.8) and Uttar Pradesh (1.7); the lowest ratios were in Andhra Pradesh, Karnataka, Kerala, Orissa and Tamil Nadu (1.0-1.1). For higher levels of deprivation, the ratios were substantially higher in all selected states, ranging from 1.1 to 5.1 for two dimensions and 1.4 to 6.0 for three dimensions. The pattern was similar for medical assistance at delivery.

The differences in postnatal care across deprivation groups were similar to those in antenatal care and in medical assistance at delivery (Table 5). States with low usage of antenatal care also had low usage of postnatal care. In general, the service coverage is higher for antenatal care than for medical assistance at delivery or postnatal care; however, in most states, the differences between those deprived in multiple dimensions and those deprived in none are smaller for postnatal care than for medical assistance at birth.

\section{Multivariate Results}

To further examine the associations between level of deprivation and use of maternal care, a set of binary logistic regressions controlling for demographic and social covariates were conducted for all states except Kerala, Tamil Nadu and Uttarakhand, because use of maternal care was high in these states and the number of women with multiple deprivations was small (Table 6). Results are presented as adjusted probabilities.
In general, the multivariate findings support those from the bivariate analyses. With a few minor exceptions, the probability of using each of the three maternal care services care decreased with increasing level of deprivation. For example, in Uttar Pradesh, the probability of receiving three antenatal checkups was 0.6 among those not deprived in any dimension, 0.3 among those deprived in one dimension, 0.2 among those deprived in two dimensions and 0.1 among those deprived in all three dimensions.

\section{DISCUSSION}

India, with its population of 1.2 billion and its diversity in socioeconomic development, provides an opportunity to

TABLE 5. Percentage of ever-married women who received postnatal care for their last live birth in the previous five years, by dimensions of deprivation; and ratio of percentages, by dimensions of deprivation-according to state

\begin{tabular}{|c|c|c|c|c|c|c|c|c|}
\hline \multirow[t]{2}{*}{ India/state } & \multirow[t]{2}{*}{ All } & \multicolumn{4}{|c|}{ Dimensions of deprivation } & \multicolumn{3}{|c|}{ Ratio of none to } \\
\hline & & None & One & Two & Three & One & Two & Three \\
\hline India & 43.9 & 60.9 & 41.7 & 26.4 & 19.9 & 1.5 & 2.3 & 3.1 \\
\hline Andhra Pradesh & 76.4 & 85.9 & 75.8 & 64.3 & 67.8 & 1.1 & 1.3 & 1.3 \\
\hline Assam & 19.7 & 35.9 & 16.0 & 9.6 & 8.8 & 2.2 & 3.7 & 4.1 \\
\hline Bihar & 17.8 & 35.4 & 15.9 & 11.6 & 7.9 & 2.2 & 3.1 & 4.5 \\
\hline Chhattisgarh & 39.2 & 54.1 & 39.9 & 29.2 & 25.0 & 1.4 & 1.9 & 2.2 \\
\hline Gujarat & 63.4 & 72.5 & 60.5 & 49.6 & 38.5 & 1.2 & 1.5 & 1.9 \\
\hline Haryana & 59.7 & 70.3 & 53.2 & 34.2 & 20.0 & 1.3 & 2.1 & 3.5 \\
\hline Jharkhand & 21.0 & 46.0 & 21.1 & 9.8 & 9.2 & 2.2 & 4.7 & 5.0 \\
\hline Karnataka & 69.4 & 81.9 & 68.4 & 47.4 & 35.7 & 1.2 & 1.7 & 2.3 \\
\hline Kerala & 91.6 & 91.9 & 91.0 & u & u & 1.0 & $\mathrm{u}$ & $\mathrm{u}$ \\
\hline Madhya Pradesh & 36.4 & 53.5 & 38.6 & 24.0 & 20.7 & 1.4 & 2.2 & 2.6 \\
\hline Maharashtra & 67.4 & 77.4 & 64.0 & 44.8 & 40.0 & 1.2 & 1.7 & 1.9 \\
\hline Orissa & 43.0 & 59.5 & 48.8 & 32.4 & 22.6 & 1.2 & 1.8 & 2.6 \\
\hline Punjab & 65.1 & 74.2 & 49.2 & 37.9 & 50.0 & 1.5 & 2.0 & $\mathrm{u}$ \\
\hline Rajasthan & 32.8 & 46.2 & 32.4 & 19.5 & 16.0 & 1.4 & 2.4 & 2.9 \\
\hline Tamil Nadu & 91.8 & 95.5 & 90.8 & 82.5 & 76.7 & 1.1 & 1.2 & 1.2 \\
\hline Uttar Pradesh & 15.8 & 27.0 & 11.8 & 7.1 & 6.0 & 2.3 & 3.8 & 4.5 \\
\hline Uttarakhand & 37.9 & 50.0 & 26.9 & 15.9 & u & 1.9 & 3.2 & $\mathrm{u}$ \\
\hline West Bengal & 46.3 & 66.1 & 43.0 & 33.5 & 31.8 & 1.5 & 2.0 & 2.1 \\
\hline
\end{tabular}

Notes: $\mathrm{u}=$ unavailable because of small sample size $(\mathrm{N}<30)$. All difference in state comparisons across deprivation groups are significant, according to chi-square tests. 
TABLE 6. Among ever-married women who had had at least one live birth in the previous five years, predicted probability of having received antenatal care and postnatal care; and among live births to such women, predicted probability of having been delivered with medical assistance-by dimensions of deprivation, according to state

\begin{tabular}{|c|c|c|c|c|c|c|c|c|c|c|c|c|}
\hline \multirow[t]{2}{*}{ India/state } & \multicolumn{4}{|c|}{ Antenatal care } & \multicolumn{4}{|c|}{ Medical assistance at delivery } & \multicolumn{4}{|c|}{ Postnatal care } \\
\hline & None & One & Two & Three & None & One & Two & Three & None & One & Two & Three \\
\hline India & 0.78 & 0.58 & 0.36 & 0.27 & 0.79 & 0.53 & 0.28 & 0.18 & 0.67 & 0.45 & 0.27 & 0.21 \\
\hline Andhra Pradesh & 0.93 & 0.85 & 0.76 & 0.64 & 0.91 & 0.76 & 0.61 & 0.62 & 0.90 & 0.80 & 0.65 & 0.74 \\
\hline Assam & 0.69 & 0.43 & 0.25 & 0.18 & 0.63 & 0.29 & 0.17 & 0.12 & 0.30 & 0.13 & 0.09 & 0.11 \\
\hline Bihar & 0.52 & 0.16 & 0.05 & 0.05 & 0.72 & 0.39 & 0.23 & 0.16 & 0.55 & 0.26 & 0.16 & 0.12 \\
\hline Chhattisgarh & 0.82 & 0.67 & 0.52 & 0.44 & 0.75 & 0.60 & 0.34 & 0.31 & 0.65 & 0.45 & 0.29 & 0.25 \\
\hline Gujarat & 0.79 & 0.65 & 0.44 & 0.33 & 0.77 & 0.59 & 0.39 & 0.25 & 0.74 & 0.62 & 0.50 & 0.40 \\
\hline Haryana & 0.75 & 0.59 & 0.38 & 0.25 & 0.75 & 0.54 & 0.22 & 0.16 & 0.75 & 0.58 & 0.36 & 0.21 \\
\hline Jharkhand & 0.70 & 0.46 & 0.25 & 0.21 & 0.73 & 0.35 & 0.17 & 0.09 & 0.53 & 0.26 & 0.11 & 0.09 \\
\hline Karnataka & 0.92 & 0.86 & 0.68 & 0.53 & 0.92 & 0.78 & 0.53 & 0.31 & 0.85 & 0.72 & 0.51 & 0.33 \\
\hline Madhya Pradesh & 0.73 & 0.56 & 0.33 & 0.25 & 0.75 & 0.51 & 0.23 & 0.16 & 0.68 & 0.48 & 0.28 & 0.24 \\
\hline Maharashtra & 0.79 & 0.65 & 0.44 & 0.33 & 0.90 & 0.67 & 0.38 & 0.34 & 0.78 & 0.65 & 0.49 & 0.41 \\
\hline Orissa & 0.79 & 0.66 & 0.46 & 0.49 & 0.76 & 0.54 & 0.27 & 0.21 & 0.59 & 0.44 & 0.28 & 0.22 \\
\hline Punjab & 0.82 & 0.58 & 0.42 & 0.25 & 0.77 & 0.75 & 0.45 & 0.33 & 0.69 & 0.40 & 0.32 & 0.40 \\
\hline Rajasthan & 0.73 & 0.49 & 0.32 & 0.19 & 0.80 & 0.57 & 0.32 & 0.20 & 0.57 & 0.36 & 0.23 & 0.19 \\
\hline Uttar Pradesh & 0.58 & 0.33 & 0.17 & 0.10 & 0.62 & 0.34 & 0.16 & 0.09 & 0.43 & 0.16 & 0.08 & 0.06 \\
\hline West Bengal & 0.86 & 0.69 & 0.54 & 0.49 & 0.87 & 0.57 & 0.30 & 0.18 & 0.67 & 0.45 & 0.35 & 0.32 \\
\hline
\end{tabular}

Notes: Adjusted for age of mother, parity, sex of child, caste, religion, region, place of residence and pregnancy complications. Predicted probability was not computed in Kerala, Tamil Nadu and Uttarakhand because of small sample sizes of three dimensions of deprivation category.

understand inequalities in health care utilization across different types of deprivation. Although prior research in India has identified household wealth, place of residence, maternal education, caste, cultural factors, type of health program and community as key determinants of the use of maternal services, ${ }^{13-21}$ little is known about inequality in use of these services across multiple deprivations. Accordingly, the aim of this study was to identify and understand these differences. The objective was not to provide numerical estimates of multiple deprivations, but to understand the differentials in basic maternal care across multiple deprivations.

This study contributes three major findings to the literature. First, the use of maternal care services-antenatal care visits, medical assistance at delivery and postnatal care-varies significantly among Indian women by level of deprivation. In general, the utilization of these services was lowest among women with all three dimensions of deprivation studied, followed by those with two dimensions and then those with one dimension; service use was highest among those not deprived in any dimension. Second, on the basis of national analyses, education exerts a greater influence on the use of maternal health services than wealth or health. Given this finding, programs using mass media or local health workers to spread information among women with low education may be effective in increasing the utilization of maternal care services. Third, the deprivationrelated inequalities in maternal care vary substantially by Indian state. In general, the differences between those with multiple deprivations and those with none appear to be high in the states where service coverage is low, and low in the states where service coverage is high. Such differences may arise from differences in availability, accessibility and quality of care in public health centers (fewer than 10\% of households usually use public health services in Bihar and Uttar Pradesh, compared with more than three-quarters of those in Tamil Nadu); ${ }^{12}$ program priority of state government; administrative efficiency; political commitment and cultural barriers.

A number of programs are being implemented to increase maternal care utilization in India. The most notable among them is the Janani Suraksha Yojana (JSY), which has been operational since April 2005. JSY is a 100\% government-sponsored scheme under the National Rural Health Mission that provides conditional cash transfers to poor and marginalized populations within India to increase institutional deliveries and postnatal care in the country. ${ }^{41}$ Studies indicate that although JSY has increased institutional delivery substantially, the poorest and the least-educated women were not those most likely to receive the benefit. ${ }^{42}$ Hence, there is a need to promote maternal care services to the poorest women.

\section{Conclusions}

This study's findings suggest that research on health inequality take into account multiple deprivations using unit data. The indicators used to define multiple deprivations should be context specific and, therefore, may not be uniform across countries. For example, if data on income or consumption expenditure are available, such indicators may be preferred to economic proxies like wealth. If the educational level of a country is relatively good, the indicators of schooling may be modified. Furthermore, trend analyses should be undertaken to understand changes in service coverage among deprived groups over time. Finally, reproductive and child health programs that attempt to identify women who suffer multiple deprivations may be effective in increasing service coverage among these groups.

\section{REFERENCES}

1. Say L and Raine R, A systematic review of inequalities in the use 
of maternal health care in developing countries: examining the scale of the problem and the importance of context, Bulletin of the World Health Organization, 2007, 85(10):812-819.

2. Lawn JE et al., Where is maternal and child health now? Lancet, 2006, 368(9546): 1474-1477.

3. Houweling TAJ et al., Huge poor-rich inequalities in maternity care: an international comparative study of maternity and child care in developing countries, Bulletin of the World Health Organization, 2007, 85(10):745-754

4. Hatt L et al., Did the strategy of skilled attendance at birth reach the poor in Indonesia? Bulletin of the World Health Organization, 2007, 85(10):774-782.

5. United Nations Development Programme (UNDP), Population, Reproductive Health and the Millennium Development Goals, New York: UNDP, 2005

6. Navaneetham $\mathrm{K}$ and Dharmalingam A, Utilization of maternal health care services in Southern India, Social Science \& Medicine, 2002, 55(10):1849-1869.

7. Sugathan KS, Mishra V and Retherford RD, Promoting institutional deliveries in rural India: the role of antenatal-care services, National Family Health Survey Subject Reports, Mumbai: International Institute for Population Science (IIPS); and Honolulu: East West Center, 2001, No. 20 .

8. Choi JY and Lee SH, Does prenatal care increase access to child immunization? Gender bias among children in India, Social Science $\mathcal{E}$ Medicine, 2006, 63(1):107-117.

9. Campbell OMR and Graham WJ, Strategies for reducing maternal mortality: getting on with what works, Lancet, 2006, 368(9543): 1284-1299.

10. Hogan MC et al., Maternal mortality for 181 countries, 19802008: a systematic analysis of progress towards Millennium Development Goal 5, Lancet, 2010, 375(9726):1609-1623.

11. You D et al., Levels and trends in under-5 mortality, 1990-2008, Lancet, 2010, 375(9709):100-103.

12. IIPS and Macro International, National Family Health Survey (NFHS 3), 2005-06; India: Vol. I, Mumbai: IIPS, 2007.

13. Mohanty SK and Pathak PK, Rich-poor gap in utilization of reproductive and child health services in India, 1992-2005, Journal of Biosocial Science, 2009, 41(3):381-398.

14. Pathak PK, Singh A and Subramanian SV, Economic inequalities in maternal health care: prenatal care and skilled birth attendance in India, 1992-2006, PLoS ONE, 2010, 5(10):e13593.

15. Ladusingh $\mathrm{L}$ and Singh $\mathrm{CH}$, Rich-poor gap in maternal care: the case of northeast India, Asian Population Studies, 2007, 3(1):79-94.

16. Hong R, Banta JE and Betancourt JA, Relationship between household wealth inequality and chronic childhood under-nutrition in Bangladesh, International Journal for Equity in Health, 2006, Vol. 5 , Art. 15, <http://www.equityhealthj.com/content/5/1/15>, accessed Jan. 11, 2012

17. Stephenson R and Tsui AO, Contextual influences on reproductive health service use in Uttar Pradesh, India, Studies in Family Planning, 2002, 33(4):309-320.

18. Houweling TA, Kunst AE and Mackenbach JP, Measuring health inequality among children in developing countries: does the choice of the indicator of economic status matter?, International Journal for Equity in Health, 2003, Vol. 2, Art. 8, <http://www.equityhealthj. com/content/2/1/8>, accessed Jan. 11, 2012

19. Pallikadavath S, Foss M and Stones RW, Antenatal care: provision and inequality in rural north India, Social Science $\&$ Medicine, 2004, 59(6):1147-1158

20. Ram $\mathrm{F}$ and Singh A, Is antenatal care effective in improving maternal health in rural Uttar Pradesh? Evidence from a district level household survey, Journal of Biosocial Science, 2006, 38(4):433-448.

21. Pande RP and Yazbeck AS, What's in a country average? Wealth, gender, and regional inequalities in immunization in India, Social Science \& Medicine, 2003, 57(11):2075-2088.
22. Kanjilal B et al., Nutritional status of children in India: household socio-economic condition as the contextual determinant, International Journal for Equity in Health, 2010, Vol. 9, Art. 19, <http:// www.equityhealthj.com/content/9/1/19>, accessed Jan. 11, 2012.

23. Akire $S$ and Santosh M, Acute multidimensional poverty: a new index for developing countries, Oxford Poverty \& Human Development Initiative (OPHI) Working Papers, Oxford, UK: OPHI, 2010, No. 38

24. UNDP, Human Development Report, New York: Oxford University Press, 1997

25. Sahn DE and Stifel DC, Poverty comparison over time and across countries in Africa, World Development, 2000, 28(12):2123-2155.

26. Bourguignon F and Chakravarty SR, The measurement of multidimensional poverty, Journal of Economic Inequality, 2003, 1(1): 25-49.

27. Calvo C, Vulnerability to multidimensional poverty: Peru, 19982002, World Development, 2008, 36(6):1011-1020.

28. Booysen F, Maltitz MV and Rand GD, Using an asset index to assess trends in poverty in seven Sub-Saharan African countries, World Development, 2008, 36(6):1113-1130.

29. Mohanty SK, Multidimensional poverty and child survival in India, PLoS ONE, 2011, 6(10):e26857.

30. UNDP, Human Development Report 2010, New York: Palgrave Macmillan, 2010

31. Sen AK, Inequality Re-examined, Cambridge, MA, USA: Harvard University Press, 1992.

32. Alkire $S$, The missing dimensions of poverty data: introduction to the special issue, Oxford Development Studies, 2007, 35(4):347-359.

33. Alkire $S$ and Foster J, Counting and multidimensional poverty measures, OPHI Working Papers, Oxford, UK: OPHI, 2009, No. 32.

34. Government of India, Planning Commission, Poverty Estimates for 2004-05, 2007, <http://planningcommission.nic.in/news/prmar07. pdf>, accessed Feb. 9, 2012

35. Mohanty SK, Alternate wealth index and health estimates in India, Genus, 2009, 65(2):113-137.

36. Griffiths PL and Bentley ME, The nutrition transition is under way in India, Journal of Nutrition, 2001, 131(10):2692-2700.

37. Nubé M, Asenso-Okyere WK and van den Boom GJ, Body mass index as indicator of standard of living in developing countries, European Journal of Clinical Nutrition, 1998, 52(2):136-144.

38. Ehrenberg HM et al., Low maternal weight, failure to thrive in pregnancy, and adverse pregnancy outcomes, American Journal of Obstetrics \& Gynecology, 2003, 189(6):1726-1730.

39. Government of India, Ministry of Health and Family Welfare (MOHFW), Reproductive and Child Health Programme: Schemes for Implementation, New Dehli: MOHFW, 1997.

40. Government of India, Office of the Registrar General \& Census Commissioner, Population Totals, New Dehli: Office of the Registrar General \& Census Commissioner, 2011

41. MOHFW, New Delhi, Janani Suraksha Yojana: Features E Frequently Asked Questions and Answers, 2006, <http://mohfw.nic.in/ WriteReadData/1892s/file28-99526408.pdf>, accessed Sept. 4, 2011

42. Lim SS et al., India's Janani Suraksha Yojana, a conditional cash transfer programme to increase births in health facilities: an impact evaLUATIon, Lancet, 2010, 375(9730):2009-2023.

\section{RESUMEN}

Contexto: Los trabajos de investigación sobre desigualdades en el uso de servicios de salud materna con frecuencia se limitan solamente al aspecto económico. Las personas y familias que viven en condiciones de pobreza aguda pueden vivir simultáneamente múltiples dimensiones de privación; las que, en conjunto, pueden obstaculizar el acceso a los servicios básicos de salud. Es importante examinar los vínculos entre las 
privaciones múltiples y la atención a la salud materna.

Métodos: Se usaron datos tomados de la Encuesta Nacional de Salud Familiar de la India de 2005-2006, para examinar el uso de servicios prenatales, asistencia médica durante el parto y servicios de atención postparto por parte de mujeres casadas alguna vez, según la privación en tres dimensiones: educación, riqueza y salud. Se hicieron análisis bivariados, análisis de componente principal y regresión logística binomial.

Resultados: Treinta y dos por ciento de las mujeres indias casadas alguna vez informaron haber sufrido privaciones en una de las tres dimensiones, $18 \%$ en dos, $7 \%$ en cada una de las tres; $y$ 43\% en ninguna de ellas. Las mujeres que sufrieron privaciones en las tres dimensiones tuvieron menor probabilidad que las que no sufrieron privaciones de haber recibido atención prenatal (probabilidades predichas, 0.3 vs. 0.8) y atención postparto (0.2 vs. 0.7). La probabilidad de que un parto tuviera asistencia médica fue menor para las mujeres con privación en las tres dimensiones que para aquellas que no sufrieron privación alguna (0.2 vs. 0.8). Estos patrones se mantuvieron para cada uno de los estados más grandes de la India. Los diferenciales en el uso de servicios de atención materna según los niveles de privación fueron mayores en aquellos estados con débil cobertura de servicios; y fueron menores en los estados con buena cobertura de servicios.

Conclusión: Se necesita más investigación para comprender cómo las privaciones múltiples se asocian con la desigualdad en materia de salud; y cómo usar este conocimiento para mejorar la prestación de servicios básicos de salud.

\section{RÉSUMÉ}

Contexte: La recherche sur les inégalités du recours aux services de soins de santé maternelle reste souvent confinée à l'aspect économique des choses. Les personnes et les familles qui vivent dans des conditions de pauvreté aiguë peuvent subir simultanément de multiples dimensions de désavantage qui, ensemble, peuvent entraver leur accès aux services de santé de base. Il importe d'examiner les liens entre les dimensions de désavantage multiples et les soins de santé maternelle.

Méthodes: Les données de l'Enquête nationale indienne 2005-2006 sur la santé et la famille servent à examiner la réception de services de soins prénatals, d'assistance médicale à l'accouchement et de soins postnatals parmi les femmes mariées ou l'ayant jamais été sur trois dimensions de désavantage: éducation, richesse et santé. L'étude procède par analyses bivariées, analyses en composantes principales et analyses de régression logistique binomiale.

Résultats: Trente deux pour cent des Indiennes mariées ou l'ayant jamais été déclarent être désavantagées sur l'une des trois dimensions, 18\% sur deux et 7\% sur les trois; $43 \%$ ne sont désavantagées sur aucune. Les fermmes désavantagées sur les trois dimensions sont moins susceptibles que celles non désavantagées d'avoir bénéficié de soins prénatals (probabilités prédites, 0,3 par rapport à 0,8$)$ et postnatals $(0,2$ par rapport à 0,7); la probabilité d'accouchement sous assistance médicale est aussi inférieure pour les femmes désavantagées sur les trois dimensions par rapport à celles non désavantagées $(0,2$ par rapport à 0,8$)$. Ces tendances s'avèrent pour tous les grands états de l'Inde. Les écarts d'utilisation des services de soins maternels à tous les niveaux de désavantage sont supérieurs dans les états où la couverture des services est faible et moindres dans ceux où la couverture est élevée.

Conclusion: De nouvelles recherches sont nécessaires si l'on veut comprendre l'association entre les désavantages multiples et l'inégalité de la santé entre les cultures et mieux cerner la manière dont cette connaissance permettrait d'améliorer la prestation de services de santé de base.

\section{Acknowledgments}

The author thanks Akankasha Srivastava and Bidyadhar Dehury, research scholars at IIPS Mumbai for their assistance.

Author contact: sanjayiips@yahoo.co.in 